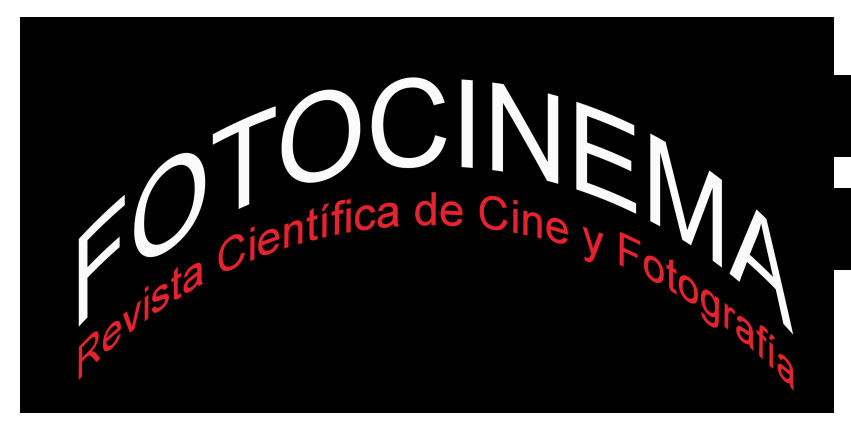

\title{
PARÍS VISTO POR CÉDRIC KLAPISCH. ENTRE LA REALIDAD Y EL SIMBOLISMO
}

\author{
PARIS SEEN BY CÉDRIC KLAPISCH. \\ BETWEEN REALITY AND SYMBOLISM
}

\author{
Alba Navarro \\ Universidad de Málaga \\ albanavarro@uma.es
}

\section{Resumen:}

La ciudad en el cine es un ámbito de investigación que propone analizar la imagen mostrada por los cineastas sobre las diferentes urbes a nivel mundial. París representa uno de los lugares estelares para el rodaje de películas. Además, es importante destacar su vinculación con el nacimiento y la maduración del séptimo arte y con el desarrollo de movimientos artísticos ligados a él. En este artículo nos sumergimos en el estudio de la película Paris (2008) de Cédric Klapisch, poniendo nuestra atención en las localizaciones elegidas por el autor para desarrollar sus historias y tratando de indagar en los motivos que le han llevado a elegir unos $u$ otros emplazamientos con los diferentes iconos parisinos. Además, estudiamos el carácter simbólico de los diversos lugares y emblemas y su influencia en el relato fílmico. En definitiva, intentamos desgranar la visión que el propio autor tiene de la metrópolis y la manera en que se la traslada al público.

\begin{abstract}
:
The city on cinema is an investigation area which proposes the analysis of the image shown by filmmakers about many cities worldwide. Paris represents one of the star places of film shooting. It is important too to highlight its connection with the origin and the growth of the seventh art and with the development of artistic movements linked to it. In this paper we dive into studying the film Paris (2008) by Cédric Klapisch, aiming our attention into the different places chosen by the author in order to develop its stories and trying to inquire the reason behind the selection of those sites with the parisian icons. Moreover, we study the symbolic character of the different places and emblems and their influence in the filmic narration. In short, we try to approach to the vision that the author has from the metropolis and the way he gives it to the public.
\end{abstract}

\section{Palabras clave:}

Cine y ciudad; cine y París; Paris de Cédric Klapisch; iconos parisinos.

Keywords:

Cinema and city; Cinema and Paris; Paris by Cédric Klapisch; Parisian icons. 


\section{Introducción}

Una línea de investigación de total actualidad en el área de estudios fílmicos es la que se centra en establecer la relación existente entre la urbe y la producción audiovisual desarrollada en ella. Podemos encontrar una gran cantidad de ciudades icónicas a lo largo de la historia del cine: Nueva York, Londres, Berlín, Madrid, Roma, Moscú, Buenos Aires, Hong Kong, Estambul... Y junto a las mencionadas comparte lugar en el pódium de enclaves estelares cinematográficos la ciudad de París.

Esta metrópolis ha sido históricamente considerada como una de las capitales más influyentes a nivel mundial, lo que en el siglo XVIII la llevó a convertirse en la capital de la Europa de las luces. Una fecha que resulta de total relevancia en estos últimos siglos para París es la de 1848. En nuestro caso nos interesan los cambios estructurales que sufrió la ciudad con posterioridad a este año y tras la llegada de Luis Napoleón al poder, que traería consigo el nombramiento, el 23 de junio de 1853, del barón Haussmann como prefecto de París, quien junto a sus colaboradores comenzó los grands travaux. Entre las remodelaciones realizadas por el barón Haussmann destacan las construcciones de amplias avenidas y bulevares. El prefecto de París implantó un nuevo callejero cuyas arterias principales confluían en plazas en forma de estrella. Además, siempre trató de asegurar que todas las nuevas calles terminaran en un elemento destacado. Así tenemos como ejemplo la plaza Charles de Gaulle, con el Arc de Triomphe de l'Étoile en el centro, conectada con una de las principales avenidas de la ciudad, los Champs-Élysées. Esta nueva visión de París, que reemplazaba a otra en la que subsistía la estructura medieval de la ciudad, trajo la modernidad a la misma (Harvey, 2008).

El proyecto del barón Haussmann ha marcado la imagen urbana actual de París. Londei (1982) expone, con respecto a este tema, que "la 'metamorfosis' de París fue la primera modernización global de la estructura urbana de una ciudad capitalista-industrial; y esto distinguió a París como el modelo de capital, a mediados del siglo XIX” (p. 85). De este modo, en el filme Paris (2008), de Cédric Klapisch, encontramos una imagen actual de la ciudad, 
una imagen de una metrópolis del siglo XXI con rasgos de esa modernidad de la que hablamos y con aquellos vestigios de un pasado arquitectónico y artístico glorioso que hoy en día se encuentra representado en tantos y tantos iconos de la ciudad.

Por otra parte, resulta interesante destacar la vinculación de la metrópolis con el nacimiento y la maduración, y en consecuencia con el esplendor, del sector cinematográfico. En la historia de este arte siempre ha ostentado una posición destacada que se ha mantenido desde sus orígenes hasta nuestros días. El 28 de diciembre de 1895 en el sótano del Grand Café, bautizado con el nombre de Salon Indien, del Boulevard des Capucines, tuvo lugar la primera proyección cinematográfica del mundo, con un coste por espectador de un franco. Ese día los hermanos Lumière proyectaron diez filmes de diecisiete metros, a los que llamaban vistas. Entre estas, las cuales fueron rodadas con el cinematógrafo, resulta de gran significación La salida de los obreros de la fábrica Lumière en Lyon. También destacaría, dentro de su prolífera filmografía, La llegada del tren, que impresionó de gran manera a los espectadores. Gubern (1998) nos habla de las razones por las que el público quedó fascinado ante aquel invento. El autor descarta los temas tratados en las películas, los cuales formaban parte de la vida cotidiana de los espectadores. Nos indica que las razones son "sus imágenes, sus fidelísimas reproducciones gráficas que, aunque reducidas a las dos dimensiones de la pantalla, conservaban su movimiento real. Fue la maravillosa capacidad de aquel artefacto para reproducir la realidad en movimiento lo que provocó el asombro y la perplejidad de los espectadores parisinos” (p. 24).

A propósito de los hermanos Lumière y del tema que tratamos, cine y ciudad, es imprescindible contemplar que estos ya establecieron una relación entre ambos factores, un vínculo en el que el cinematógrafo capta las imágenes de un Lyon en calma en los últimos años del siglo XIX. A ellos se les atribuye el primer gran travelín de la ciudad en su filme Panorama de la llegada del tren a la estación de Perrache, donde la maquinaria entra en la ciudad desde el norte. Sin rastro de presencia humana, la cámara capta los bloques de apartamentos, las chimeneas de las fábricas, la silueta de la basílica de Lyon, el río, vallas publicitarias y, finalmente, la estación. Siguiendo con las 
creaciones de los grandes pioneros del cine, queremos poner algún ejemplo de su producción localizada en París. Encontramos obras como Los fosos de las Tullerías o, presentándonos un concurrido escenario parisino, La Avenida de los Campos Elíseos. Si bien en estos casos la función del cinematógrafo era eminentemente documental, los lugares elegidos en los inicios del cine coincidirán en gran número de ocasiones con los escenarios actuales del París cinematográfico.

\section{Marco teórico}

En las investigaciones que ponen en relación los conceptos cine y ciudad encontramos que París es uno de los enclaves más destacados para el análisis. La urbe es examinada por diferentes autores con focos de estudio diversos. Villanueva (2008) propone un análisis dual sobre las imágenes de la ciudad, desde la poesía y desde el cine. El autor nos remonta al año 1900, en el que James White realizó para Edison cinco "Paris Exposition Films" con los siguientes títulos: Eiffel Tower from Trocadero Palace, Palace of Electricity, Champs de Mars, Panorama of Eiffel Tower y Scene from Elevator Ascending Eiffel Tower. En el mismo año en que tuvo lugar una de las exposiciones universales, son las propias productoras norteamericanas las que centran su atención en la capital francesa, pudiéndose establecer un paralelismo entre la Torre Eiffel y los rascacielos neoyorquinos.

Uno de los referentes más notorios para nuestro ámbito de estudio, que también nos ofrece información sobre la relación entre la capital francesa y el celuloide, es el libro Ciudades proyectadas. Cine y espacio urbano, de Stephen Barber, publicado originariamente en 2002 y en su versión en castellano en 2006. El autor indaga sobre los orígenes de la ciudad fílmica, el espacio urbano en el cine europeo y en Japón y, por último, dedica un capítulo a la ciudad digital y el cine. Otra lectura, del año 2007, es la del libro Ciudades del Cine, de Rafael Dalmau y Albert Galera. En la obra se dedica un capítulo a París, bajo el enunciado "Donde todo el mundo se mueve por amor". Los autores, en este caso, hacen un repaso de la imagen de la metrópolis en cuatro películas de gran reconocimiento: Amélie (2001), Al 
final de la escapada (1960), Les rendez-vous de Paris (1995) y Paris, je t' aime (2006).

Además, ha sido publicado en los últimos años el catálogo de la exposición Paris vu par Hollywood, presentada en la sala Saint-Jean, entre el 18 de septiembre y el 29 de diciembre de 2012, por el departamento de exposiciones del Ayuntamiento de París. El comisariado se encontró a cargo de Antoine de Baecque, quien ha elaborado varios de los textos que forman parte del catálogo, y, junto a él, distintos expertos en la materia repasan a lo largo de la historia del séptimo arte las imágenes de París, lugar para la inspiración, en el cine de Hollywood. En el año 2013 encontramos el libro Ciudades europeas en el cine, coordinado por Gloria Camarero. Y, como publicación más reciente, destacamos la obra Ciudades de Cine, coordinada por Francisco García y Gonzalo M. Pavés. En ella, Ángel Luis Hueso reflexiona sobre las imágenes cinematográficas de París a lo largo de la historia. A pesar de ser un trabajo parcial en cuanto a la selección filmográfica, el autor expone su intención de ofrecer una visión global, significativa y valorativa del conjunto de filmes.

Seguidamente, apuntamos dos momentos de gran significación que evidencian la importancia de la imagen de la ciudad de París a lo largo de la historia del cine. El primero lo encontramos en la década de 1920. Fijando su atención en la figura de los surrealistas en la segunda mitad de esta década, Barber (2006) expone que "se centraron en la representación de formas urbanas yuxtapuestas a la dinámica de la percepción sensorial; el cuerpo adquirió y perdió su preeminencia como punto de intersección entre la imagen y la ciudad" (p. 8). Hueso (2013), asimismo, revisa la representación de las ciudades europeas ante el objetivo de la vanguardia. El cine, con sus grandes posibilidades expresivas, y el mundo urbano creaban fascinación en los vanguardistas, que unieron estas dos tendencias. Fuera de toda duda, indica, se encuentra la importancia que tuvieron en este momento histórico ciudades como Berlín o París. El autor además explica que "las ciudades eran contempladas por los artistas desde un punto de vista vitalista como un organismo sometido a continuas transformaciones" (p.16). El segundo momento al que nos referimos lo encontramos con los cineastas de la 
Nouvelle Vague que surgieron a finales de la década de 1950, convirtiéndose en el germen de este movimiento la revista Cahiers du Cinéma. Ferré (2001) resalta la idea de que estos cineastas salieron a filmar a las calles, siendo la ciudad, con anterioridad a ellos, una simulación promovida por el cinéma de qualité de los años cincuenta. Así Godard había fundado una ciudad nueva, explica, que se asomaba a un concepto nuevo de la geografía urbana. Domínguez (1998), en este caso, nos habla de que "Truffaut, Godard, Rohmer o Malle filmarán, como lo hicieron los maestros de los años treinta, el traje de a diario de la Ciudad de la Luz” (p. 179).

Por otra parte, resulta muy interesante un concepto empleado por Mascarenhas (2013), el de atlas fílmico, para el análisis de varias de las películas de Sacha Guitry y Jacques Tati localizadas en París. En el primero de los cineastas el atlas de París se construye en base a cuatro elementos principales: espacios reconocibles e identificables por el gran público, el tiempo histórico, eventos históricos y personajes históricos. Sus principales obras aquí son: Remontons les Champs-Elysées (1938), Si Versailles m'était conté (1954) y Si Paris nous était conté (1956). Sin embargo, en el caso de Tati la construcción del atlas de la ciudad se produce a partir de fragmentos de su propia psicogeografía. En esta ocasión se nos remite a las películas Mon Oncle (1958) y Playtime (1967).

Con un carácter más general, sobre el estudio del cine y la ciudad, queremos referirnos a un artículo elaborado por Yeste (1994-95), en el que defiende la idea de que el cine resulta una fuente documental para reconstruir la historia urbana de la ciudad. La autora señala que, cuando la filmación de la película en cuestión se ha producido en escenarios naturales, se nos muestra de forma inequívoca cómo es el entorno urbano que acogió el rodaje. Por otro lado, si se ha realizado en escenarios irreales o construidos, se nos aproxima a un tipo de concepción estética. También creemos relevantes unas palabras escritas por Camarero (2013) en relación con el papel de la ciudad en la pantalla:

Es signo y significado de la acción. Expresa determinadas formas de vida de sus habitantes a la par que contribuye a definir el carácter, las circunstancias 
y la diversidad que rodea a cada uno de ellos. Puede ser transgresora, distinta, universal, cosmopolita e, incluso, el espacio imaginado y soñado que se exhibe desde el subconsciente, metamorfoseada en aras del recuerdo. Se nos presenta como trasfondo de conflictos bélicos, destrucciones masivas, intensos movimientos migratorios, crisol de razas y culturas. Es el espejo donde se proyectan las diferencias sociales y culturales. Cobija y arropa a las personas que la transitan. Unas veces se exhiben sus edificios, establecimientos y barrios más conocidos a modo de postal turística y otras, los más recónditos. Con frecuencia, su fisonomía cambia a medida que lo hacen los comportamientos de los protagonistas. Actúa como un personaje más dentro de la trama y tiene el mismo valor argumental que cualquiera de ellos (p. 5).

\section{Metodología}

La elaboración de este artículo se enmarca dentro de un trabajo de investigación de mayor amplitud, que tiene como principal objetivo indagar en la imagen de la ciudad de París en el séptimo arte, desde el año 1920 hasta el año 2014, a través de una muestra compuesta por 152 películas.

El filme Paris forma parte de la muestra que se corresponde con la década que comienza en el año 2000. Es una película cuya relevancia reside en la importancia que el cineasta otorga a la ciudad, que en sí misma ostenta un papel protagonista. Esta intencionalidad se aprecia en el propio título de la obra.

La información extraída del análisis cualitativo, que es el que nos ocupa a lo largo de las páginas de este artículo, nos permitirá establecer conexiones con el resto de películas que forman parte de la filmografía seleccionada. De este modo, se podrán recopilar aquellos puntos de interés que han ido repitiéndose a lo largo de la historia del cine en la representación de la imagen de París, al igual que será posible señalar aquellas singularidades que se descubran en las producciones. En el análisis cualitativo que hemos llevado a cabo en esta ocasión, hemos realizado un registro de las localizaciones elegidas para el desarrollo de las diferentes tramas en el filme Paris. No solo nos hemos centrado en el análisis de los escenarios 
principales, por el contrario, hemos creído imprescindible establecer un estudio detallado de todos aquellos lugares que pasan de manera fugaz ante los ojos del espectador y que, a pesar de su efímera presencia, contribuyen de manera complementaria a la creación de conceptos dentro de la película.

El registro realizado nos ha permitido establecer nexos entre las localizaciones y los personajes y relatos. De esta manera, hemos podido identificar aquellos rincones parisinos que han servido al autor para dar coherencia a la narración. Para Cédric Klapisch el callejero parisino no es un simple escenario. La ciudad está viva y se transforma al ritmo en que lo hacen sus habitantes. Nuestras indagaciones nos han permitido identificar el simbolismo que subyace tras los espacios, los cuales han sido seleccionados en función de su significación para el imaginario sobre la urbe.

\section{Paris: la ciudad representada}

En la primera escena de Paris, un filme de historias entrecruzadas, aparece el cielo de la metrópolis ausente de su gran icono de la modernidad (F1). La cámara nos descubre a Roland Verneuil (Fabrice Luchini), que aparta la vista del inmenso paisaje urbano para fijarla en la cumbre de la estructura de hierro (F2). Se trata de un flashforward, en el que la Torre Eiffel hace acto de presencia como elemento que inaugura el devenir de localizaciones parisinas. Sin duda, Cédric Klapisch otorga a este monumento una posición destacada dentro de la geografía urbana de la ciudad, por ello le ofrece esa posibilidad de actuación en primer lugar dentro de lo que es una creación sinfónica sobre París.

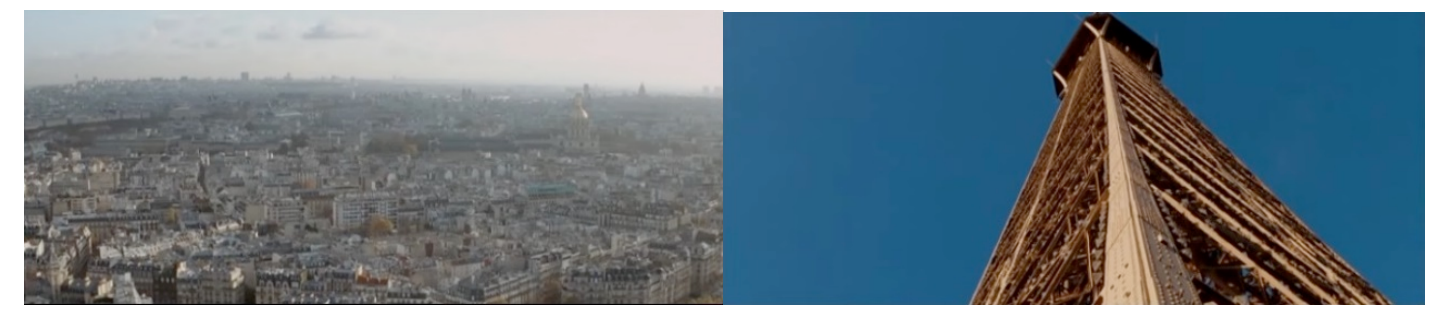

F1. El cielo parisino sin su icono de la modernidad. F2. La Torre Eiffel hace acto de presencia 
Le siguen la presentación de lugares y personajes, entre un ritmo natural y acelerado. El blanco invade la pantalla, la basílica del Sacré-Coeur nos sitúa en Montmartre (F3). Laetitia (Mélanie Laurent) camina apresurada y en segundo plano, el Panteón de París. Un coche conduce por la Rue Étienne Marcel, sus cristales están mojados y es activado el limpiaparabrisas, su trayectoria lo lleva hasta la Plaza de las Victorias con una estatua ecuestre de Luis XIV en su centro. Más adelante seguirá su trayecto por la Rue de Rivoli, cruzándose de manera perpendicular con la Rue de Castiglione, que nos deja admirar fugazmente la Columna Vendôme, situada al fondo en la plaza homónima. La Ópera Garnier y el Moulin Rouge, en el Boulevard de Clichy de Montmartre, serán otros de los elementos que completen este recorrido introductorio por las calles de París. Tal vez estas primeras imágenes del filme no estén tan alejadas de las que configuraban las primeras obras de la historia del cine. Barber (2006) nos habla de los inicios de este arte, que "comenzó con una dispersión de espectros gesticulantes, de cuerpos humanos transitando las calles de la ciudad, enmarcados por perfiles de puentes, hoteles y almacenes, bajo cielos industriales contaminados" (p. 13). Desde la ficción, Cédric Klapisch nos presenta aquí un espacio que no difiere tanto de lo primigenio, conecta con ello en ese ir y venir de las gentes por los rincones parisinos, también bajo su techo y al abrigo de sus edificios y monumentos, que los acompañan en su día a día y que forman parte del decorado donde desempeñan sus quehaceres cotidianos.

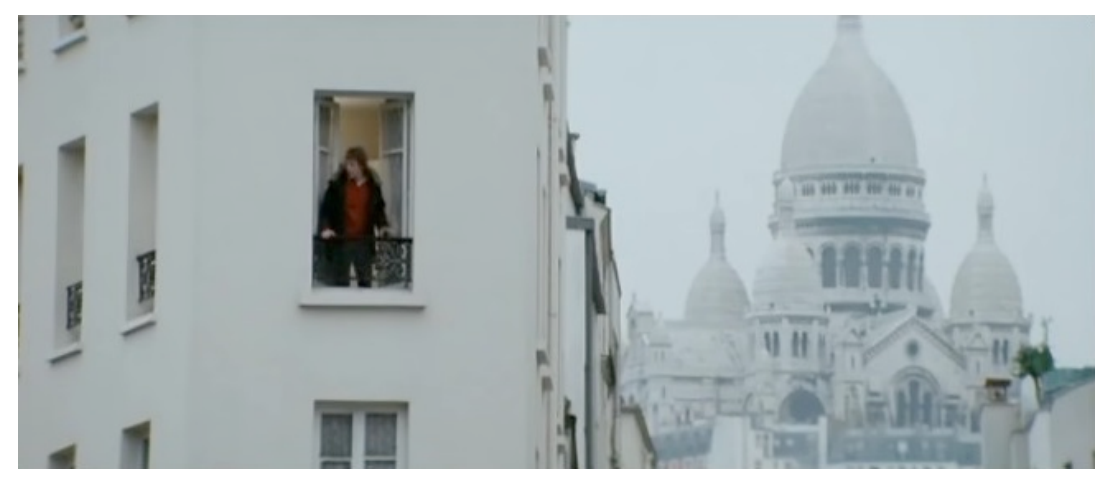

F3. El Sacré-Coeur nos sitúa en Montmartre

Gran parte de la trama de la película se sitúa en el distrito 20, en torno al cementerio Père Lachaise. Pierre (Romain Duris), un joven enfermo del corazón, pasa las horas mirando por la ventana de su piso, emplazado junto a 
la necrópolis (F4). Desde ella ve vivir a los demás y al verles se pregunta quiénes son y a dónde van. Son los héroes de las historias que inventa. En un primer momento, y también en otras ocasiones a lo largo del filme, las vistas de su ventana recogen una estampa en la que la Torre Eiffel se sitúa a la derecha del plano y la Torre Montparnasse a la izquierda. Si dibujáramos una línea imaginaria que uniera ambas torres entre sí y con la ventana de Pierre, encontraríamos que se forma un triángulo en el que cada uno de los elementos es un vértice, y dichos vértices coincidirían por tanto con los puntos de interés que resalta el autor, siendo estratégicamente organizados en el cuadro. Más adelante, desde la misma ventana, Cédric Klapisch nos descubre la compañía del cementerio que, aunque camuflada por los árboles, en todo momento deja sentir su presencia, como ya explicaremos. Este lugar sacrosanto aparecerá de una manera más explícita durante el entierro del padre de los hermanos Verneuil; el segundo de ellos, Philippe, interpretado por François Cluzet. Las tumbas aparecen como filas ordenadas. Los hombres abandonan el cementerio, caminando abrazados por una de las calles. La brisa balancea las hojas de los árboles, que en tonos verdes y anaranjados nos sugieren un paisaje otoñal ( $\left.\mathrm{F}_{5}\right)$. El autor plantea una imagen hermosa.

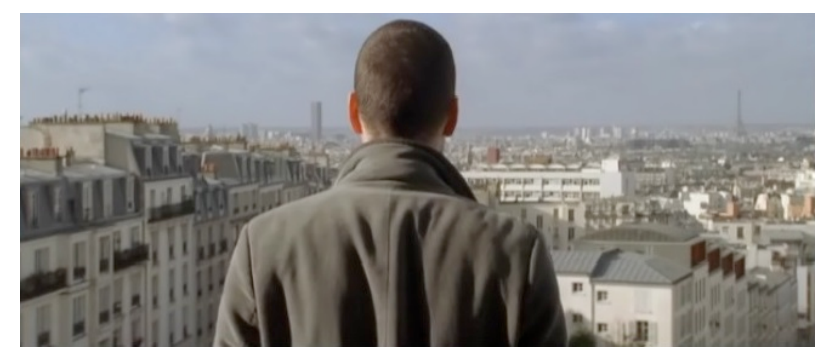

F4. Vistas desde la ventana de Pierre

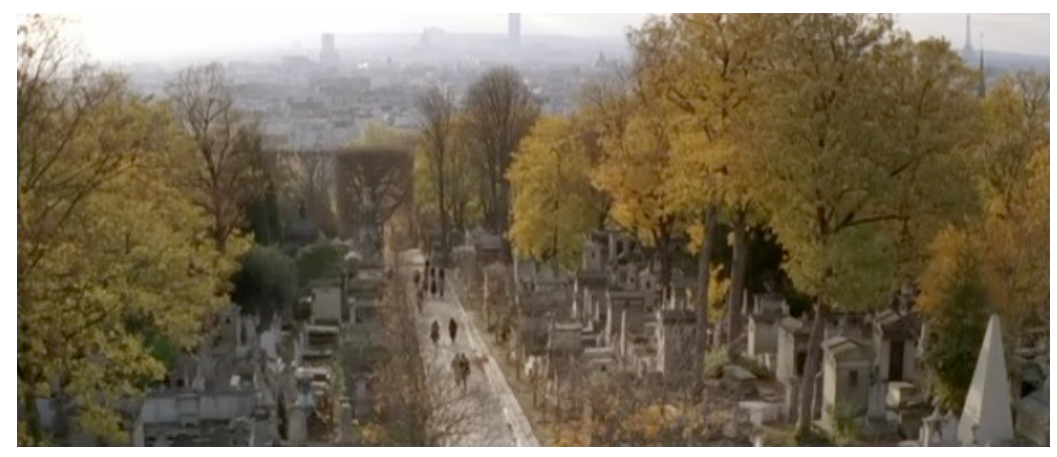

F5. Un hermoso paisaje otoñal en el cementerio Père Lachaise. 
En relación con dos elementos que hemos destacado con anterioridad: la Torre Eiffel y la Torre Montparnasse, estos adquieren una importancia más allá de situarse ante los ojos de Pierre. Sobre la Torre Eiffel ya hemos discutido previamente el papel que desempeña al comienzo de la película. Más adelante la secuencia, que es anunciada a través de un flashforward, se desarrolla completamente. Roland, historiador especializado en la ciudad de París, ha sido contratado para trabajar en un programa televisivo de divulgación sobre su especialidad. Entonces se encuentra en el icono de hierro parisino. Allí, desde un telescopio, pone su mirada en la Torre Montparnasse, donde se encuentra a un hombre diminuto por la lejanía, Jean (Albert Dupontel), quien esparce las cenizas de Caroline (Julie Ferrier), que se pierden en un cielo gris (F6). Después, al ver el Sacré-Coeur, recuerda a Laetitia, su alumna y de la que está enamorado. La joven se encuentra allí con un compañero dibujando una típica postal turística, hecho que ellos mismos comentan. Los dos están sentados en las escalinatas, justo con la basílica a sus espaldas y el universo parisino a sus pies ( $\mathrm{F} 7)$.
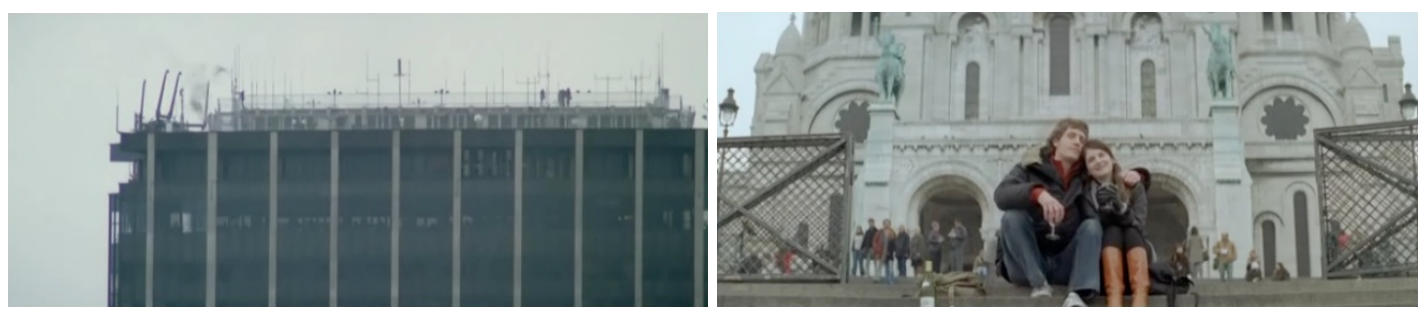

F6. Jean esparce las cenizas de Caroline. F7. Estampa turística en el Sacré-Coeur

Precisamente es el personaje de Roland el responsable de introducir en el filme un gran número de localizaciones a partir de diferentes líneas argumentales. Una de ellas se centra en las emisiones televisivas de divulgación histórica en las que participa. El trato de su incorporación en dicho programa se cierra en un establecimiento junto a los jardines del Palacio Real, en una conversación que Roland mantiene con un presentador de televisión (F8). En un posterior plano general un grupo de turistas, con su respectivo guía, entra en cuadro (F9). En el París de Cédric Klapisch se muestran esas dos caras de la ciudad: la de lo cotidiano y la de lo excepcional. Los habitantes en su normalidad, y sin poder ser ajenos a su entorno, conviven con la sorpresa y la fascinación de los viajeros. 


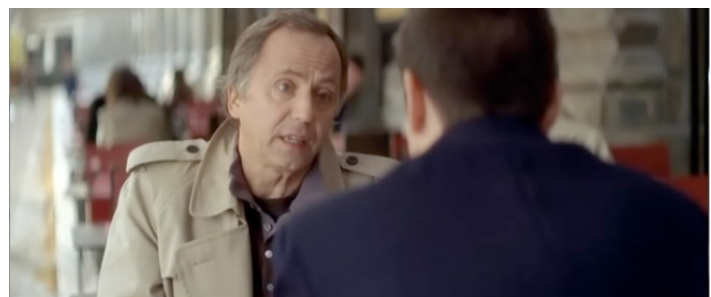

F8. Roland conversa con el presentador

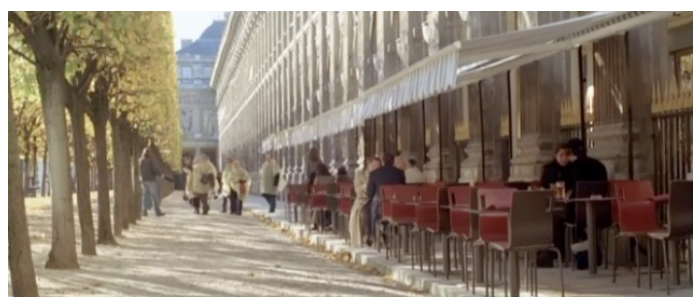

F9. Los turistas entran en cuadro

También en los primeros minutos de la película, el presentador se encuentra en pleno rodaje, hablando de la ciudad de París y de las ideas asociadas a ella. La escena se localiza junto al Sena y en las inmediaciones de la catedral gótica de Notre-Dame, situada en la Île de la Cité, que también es mostrada. Un músico toca el acordeón. La silueta de la Torre Eiffel aparece claramente dibujada como telón de fondo, retratándose de esta manera una imagen totalmente reconocible y tópica sobre París. Otros espacios donde tiene lugar la filmación del programa son el Hôtel de Lauzun (S. XVII), ubicado en el Quai d'Anjou en la île Saint Louis, y las Catacumbas (S. XVIII), que se encuentran en la Avenue du Colonel Henri Rol-Tanguy. En el primero de ellos Roland comienza el retrato de París apoyándose en la figura de Baudelaire, quien supo expresar de manera magistral su sentir hacia la ciudad a través de la poesía. En cuanto a las Catacumbas, encontramos un escenario inquietante con montones de huesos y calaveras, donde Roland se siente impedido para continuar con la grabación.

A propósito de la siguiente línea argumental relacionada con este personaje, hemos elegido unas palabras de Benjamin (2013) con las que crea una metáfora en torno a la impresionante urbe. Este dice que "las calles son los apartamentos de la gente. La gente es un ser colectivo en perpetuo movimiento, en perpetuo trasiego, que vive, experimenta, descubre e inventa ante las fachadas tanto como los individuos al abrigo de sus cuatro paredes" (p. 40)1. En este caso encontraremos espacios principalmente abiertos, con excepción de las instalaciones de la Sorbona, donde en una gran aula, repleta de estudiantes, Roland descubre por primera vez un rostro que le fascina, el

\footnotetext{
${ }^{1}$ Este fragmento pertenece a una selección de apuntes reunidos por Benjamin entre 1927 y 1929 y entre 1934 y 1940 para su proyecto de libro sobre París y la historia social del siglo XIX.
} 
rostro de Laetitia, entre otros individuos invisibles. El profesor se convertirá en un voyeur, que espía a través de los cristales del café a Laetitia, cuya contemplación le hace sentir gran placer. Cabe señalar que esta además es observada por Pierre, quien también siente atracción por ella, ya que su vivienda se encuentra justo frente al edificio del joven. En una de estas ocasiones en el café, Roland utiliza los versos de Baudelaire en su poema A la mujer demasiado alegre, e incluso diciendo que es el propio poeta, para dirigirse a su pupila amada. Con cierta inquietud, Laetitia emprende su camino por las calles de París. En primer lugar, nos remonta a una de las imágenes introductorias del comienzo del filme, la joven con su caminar apresurado nos presenta en un segundo plano al Panteón de París. Después se nos sitúa en los Jardines de Luxemburgo. Los árboles en cobre nos presentan un paisaje caduco donde tres hombres practican Tai Chi. El tiempo parece pausado, los movimientos son lentos y el temple tranquilo. Los pasos de Laetitia atraviesan un ambiente en calma (F10). Finalmente, ambos personajes mantendrán varios encuentros sexuales, que harán rejuvenecer a Roland. Sin embargo, estos no supondrán más que un entretenimiento para Laetitia, la cual mantiene una relación paralela con un chico de su edad. Por ello, querrá que Roland vea su vida. Cédric Klapisch emplaza la acción en el café Aux Folies, situado en el número 8 de la Rue de Belleville, también dentro del distrito 20 de París, aprovechando las grandes ventanas de este pintoresco establecimiento.

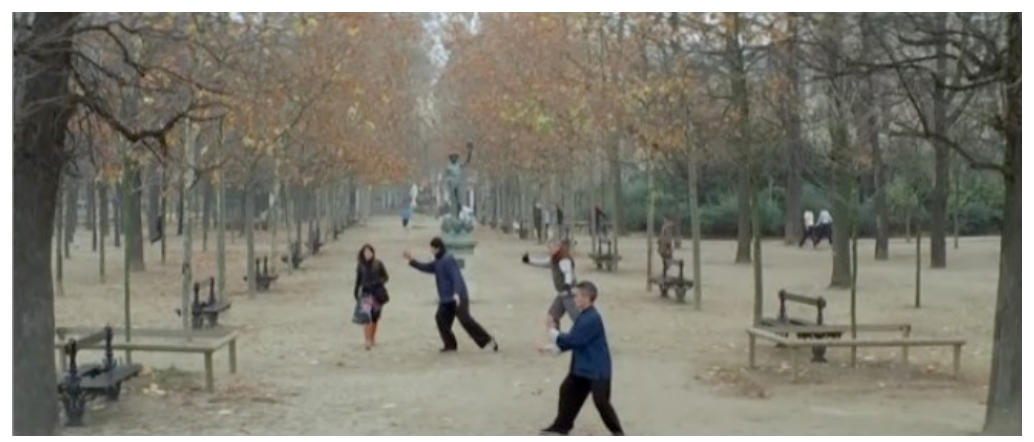

F10. Laetitia atraviesa los Jardines de Luxemburgo

La última línea argumental en torno a Roland es la que retrata la relación con su hermano Philippe. Este último vive en un apartamento ubicado en el distrito 13 de París. Desde una de las perspectivas de su terraza se nos 
presentan las impresionantes vistas que dan a la Biblioteca Nacional de Francia-François Mitterrand, que se encuentra formada por cuatro torres con formas de libro abierto. Aquí Roland le entregará a su hermano un grabado del siglo XVII que muestra otra de las vistas de la terraza. Se destaca de este modo la metamorfosis experimentada por la ciudad a lo largo de los años, décadas y siglos.

Por último, hablaremos de la secuencia de imágenes que presentan el recorrido de Pierre desde su piso hasta el hospital donde va a ser operado. $\mathrm{Su}$ historia quedará inconclusa. Se despedirá de su hermana y cogerá un taxi, enfrentándose a un final incierto. A través de la ventana del vehículo Pierre avistará una de las entradas al cementerio Père Lachaise, la Plaza de la Nación con el Triunfo de la República y al fondo las columnas de la Avenue du Trône. El recorrido seguirá por la Ópera de la Bastilla y la Columna de Julio, rematada por el Espíritu de la Libertad, en la Plaza de la Bastilla. Pierre también pondrá su atención en Benoît (Kingsley Kum Abang), un camerunés recién llegado a París, que observa cómo se eleva ante sus ojos la catedral de Notre-Dame, que un día llegó a sus manos a través de una postal. En los últimos momentos de su viaje, Pierre sonríe mirando al cielo ante la ironía que representa su belleza azul, que cobija a las personas durante la vida y que es su destino ante la muerte.

\section{Paris: la ciudad que siente}

La ciudad adquiere un significado propio, metafórico en cada rincón, nos habla por sus lugares, nos cuenta historias que se reflejan en sus entornos y que son captadas por la cámara cinematográfica. Encontramos que, en su interacción con la ciudad, las películas "revelan elementos de formas corpóreas, arquitectónicas, históricas y sociales, a la vez que proyectan inquietudes vinculadas a la memoria, la muerte y los orígenes de la imagen que sellan de un modo crucial el cine y el espacio urbano" (Barber, 2006, p. 7). Por su parte, Ferré (2001) nos habla de la dificultad para "encontrar al cineasta capaz de entender el espacio urbano en términos a la vez concretos 
(como presencia, justamente) y abstractos (como irrealidad, fantasmagoría, premonición)” (p. 58).

En Paris la ciudad rezuma dolor ante la muerte y frescura ante la vida. También indiferencia. Cédric Klapisch ha sabido exprimir aquellas reminiscencias simbólicas de los lugares que capta con la cámara. Sin duda, el lugar que emana mayor significación es el cementerio Père Lachaise. El propio Roland, con respecto a la muerte de su padre a los 95 años, dice que llegar hasta esa edad es toda una victoria. Esta idea de la victoria por haber podido disfrutar de una vida longeva se opone a la injusticia de encontrarse al filo de la muerte en una edad temprana, como es el caso de Pierre y Caroline. En relación con Pierre, la figura del cementerio, que representa su posible destino, lo acecha. Es una localización con la que convive diariamente y que, aunque no lo pretenda, observa cada día desde su balcón (F11). Recordemos, además, que en el camino hacia el hospital en taxi su mirada se cruza con una entrada al recinto, lo que puede leerse como una premonición. Así, la muerte hace presencia, anunciándole su trágico final, que, realmente, desconocemos. La enfermedad fulmina las ilusiones de quien fuera un risueño bailarín de cabaret; por ello, el Moulin Rouge al comienzo del filme y el color de los espectáculos que él recuerda.

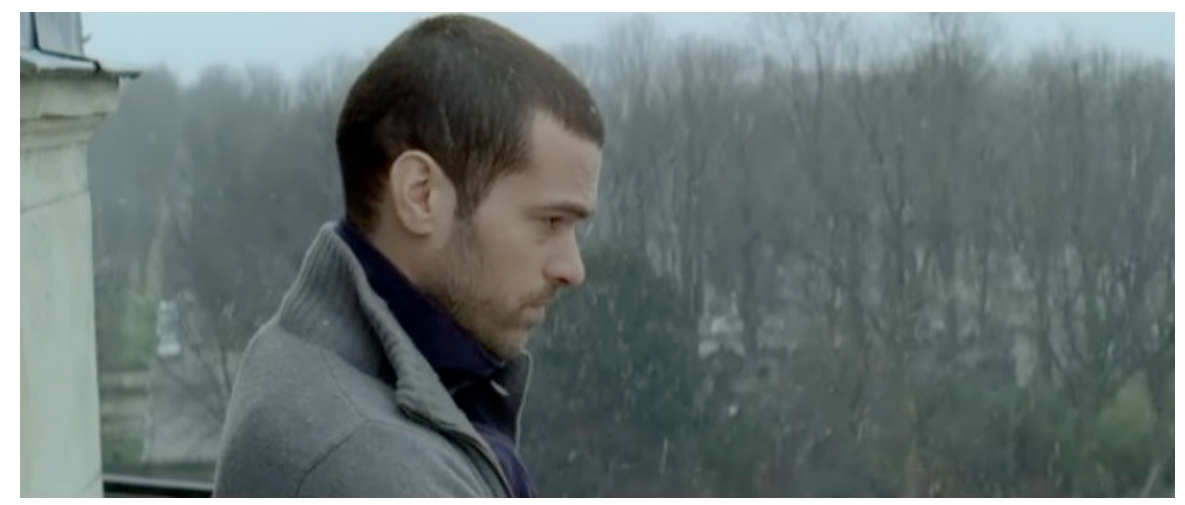

F11. Vistas desde el piso de Pierre del cementerio Père Lachaise

En el segundo caso, el de Caroline, la muerte llega de manera impactante, sobrecoge. Nadie espera este suceso, por lo que resulta realmente traumático. Tras su accidente, encontramos una secuencia de imágenes de la ciudad: papeleras cuyas bolsas son agitadas por el viento (F12), el tronco de un árbol y un semáforo, una boca de metro con una persona saliendo de ella (F13), 
ventanas (F14), un hombre cruzando la calle, algunos paseantes, niños que juegan en el recreo (F15), el cielo de París visto desde la ventana de Pierre y él en su ventana. Aquí podemos hacer una interpretación desde dos perspectivas diversas. La primera nos lleva a contemplar una ciudad imperturbable, marcada por la pasividad y ajena al drama. La segunda nos lleva a contemplar una ciudad en la que la inusual calma retrata la ausencia de vida y, por tanto, retrata la muerte. Esto ocurre en todas las imágenes excepto en la de los niños jugando, que a través de su jovialidad, propia de una edad temprana, plantan cara a la Parca. Las cenizas de Caroline, como ya comentamos con anterioridad, son arrojadas desde la Torre Montparnasse por Jean. Este elige un edificio que se encuentra ligado a sus recuerdos con ella, ya que cuando llegaron de la Bretaña a París la visitaron al salir de la estación. La torre representa el principio y el fin de Caroline en París. Representa su desaparición del mundo terrenal, porque la cúspide de una torre es lo que más nos aleja del suelo, y representa su vinculación definitiva con el universo a través de su unión a un cielo en luto. La muerte siempre aparece en el filme; también a través de las Catacumbas, porque de entre todos los escenarios posibles el director eligió este lugar siniestro.
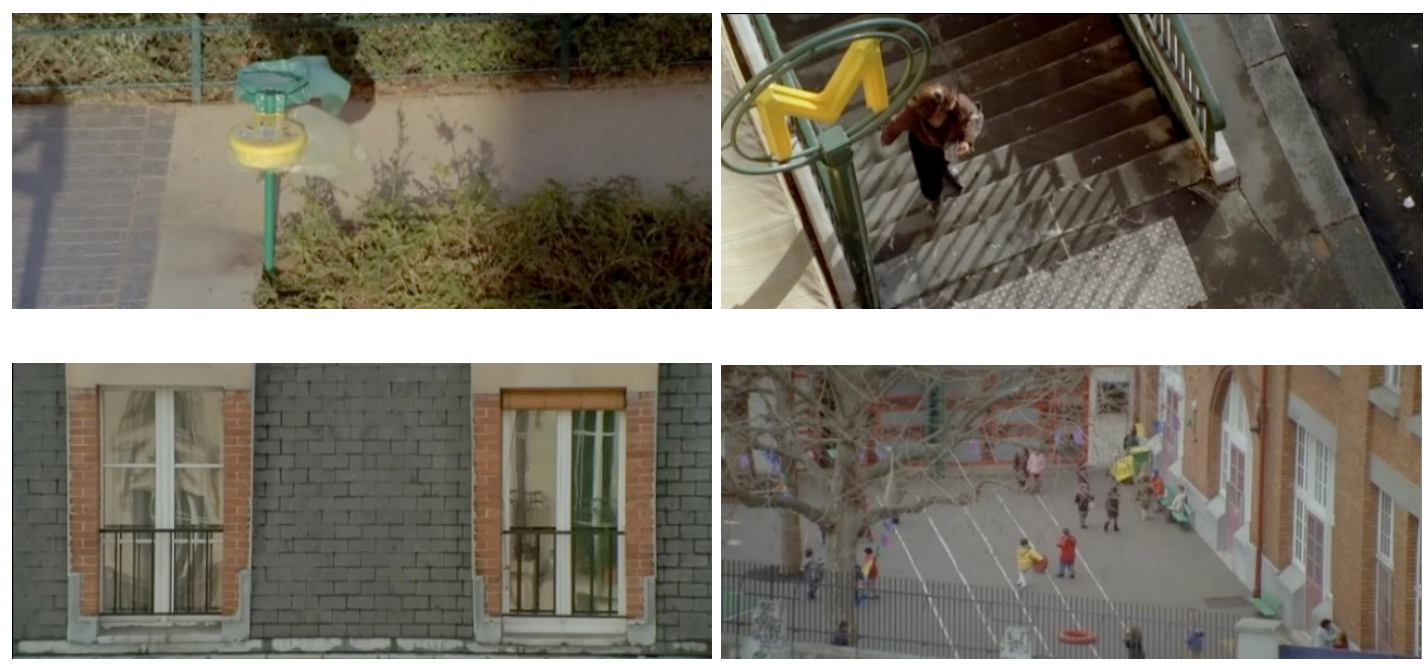

F12, F13, F14 y F15. Imágenes tras el accidente de Caroline

A pesar de todo, la esperanza también está presente y con ella el futuro. Benoît en su camino encontrará las vicisitudes del exilio y se enfrentará cara a cara con el infinito del océano, que puede ofrecerle tanto la vida como la muerte. El mar ante el que se encuentra representa también una ventana, 
como la de Pierre, que no puede ofrecerle una respuesta ante sus dudas y, como al joven enfermo, lo único que le queda es sacar valor y enfrentarse a sus circunstancias y al devenir de los acontecimientos. Finalmente Benoît llega a su destino y reconoce su triunfo ante lo desconocido. Contempla Notre-Dame y contempla la postal que un día recibió. La catedral representa el éxito de su viaje porque ahora se encuentra ante su presencia y no es solo una idea en su mente, ni un propósito. También debemos quedarnos con esto, la ciudad es pasado, es presente, pero ante todo, es futuro.

\section{Conclusiones}

Paris no pretende ser una película tópica sobre la capital francesa, pero tampoco puede ser ajena a ese tipo de reminiscencias y significados, que también asume. Cédric Klapisch recoge una pluralidad de visiones sobre la ciudad, que forman un caleidoscopio de vivencias representadas en las diversas líneas argumentales del filme. Cada uno de los lugares, iconos, emblemas, localizaciones..., y, en definitiva, cada uno de los escenarios parisinos, que configuran este extraordinario plató de rodaje, aporta un valor especial a cada historia. De hecho, les aporta tal grado de singularidad, que no podrían haber sido reproducidas de igual manera en ninguna otra ciudad. Los emplazamientos han sido elegidos con gran meditación, valorando también el conocimiento de un público no francés sobre la propia geografía urbana de París. Por ello, la Torre Eiffel, Notre-Dame, el Sacré-Coeur, o el cementerio Père Lachaise, una de las necrópolis con mayor notoriedad a nivel mundial, en la que encuentran sepultura personajes de gran celebridad como Honoré de Balzac, Oscar Wilde o Édith Piaf. Y no olvidemos que Benoît recibe una postal con la fotografía de la catedral de Notre-Dame, por lo que en el propio filme se reconoce el poder notorio de las imágenes de París más allá de sus fronteras.

Una de las características más potentes, que poseen las localizaciones de la película, es su poder simbólico. Estas nos hacen referencias, principalmente, a dos momentos de la vida de los seres humanos: la plenitud de la juventud vinculada a la salud, y la enfermedad y la muerte ligadas a la idea de la 
fugacidad de la vida o lo efímero. La juventud representada por la Sorbona, el Moulin Rouge, el café Aux Folies e, incluso, por las atracciones infantiles instaladas en una calle cualquiera de París, donde Roland recibe con indiferencia la noticia del nacimiento de su sobrino, creándose de este modo una situación irónica. En el caso de la muerte, su principal representante es el cementerio Père Lachaise, pero también las Catacumbas, el Panteón de París y, sin quererlo, los Jardines de Luxemburgo por su atmósfera perecedera y, por supuesto, la Torre Montparnasse al acoger la despedida de Caroline y su total desaparición.

Nuestras primeras palabras sobre Paris se referían a una creación sinfónica, añadimos ahora, cuyas notas musicales se encuentran esparcidas por un pentagrama de calles, barrios y distritos. Cédric Klapisch no es excluyente; por el contrario, sabe que para entender París hay que entenderlo en su absoluto: Montmartre, el distrito 20, la Île de la Cité, etc. Este privilegiado entorno, rico por lo que cada época ha aportado a su estructura urbana, se vuelve casi mágico para los viajeros, casi ordinario para sus habitantes, aunque no podemos dejar de decir que se trata de una extraordinaria cotidianidad la que los rodea. París, la ciudad vista por Cédric Klapisch, al igual que la real, es emocionante, policroma, vibra con las pisadas de las gentes en el asfalto, nos eleva al cielo y nos sumerge en lo subterráneo y, ante el veredicto de la muerte, decreta un canto a la vida.

\section{Referencias bibliográficas}

Barber, S. (2006). Ciudades proyectadas. Cine y espacio urbano. Barcelona: Gustavo Gili.

Baudelaire, C. (1982). Las flores del mal. Madrid: Visor Libros.

Benjamin, W. (2013). París. Madrid: Casimiro libros.

Boespflug, B. \& Billon, B. (2014). Paris fait son cinéma. París: Éditions du Chêne.

Camarero, G. (2013). Escenarios para el reencuentro. En G. Camarero (Ed.), Ciudades europeas en el cine (pp. 5-14). Madrid: Ediciones Akal.

Dalmau, R. \& Galera, A. (2007). Ciudades del cine. Barcelona: Raima Edicions.

De Baecque, A. (Dir.) (2012). Paris vu par Hollywood. París: Skira 
Flammarion.

Domínguez, O. (1998). Las ciudades soñadas: París y Viena. En C. Carreras \& C. Crespo (Coords.), Cien años de cine: la fábrica y los sueños (pp. 171-180). Sevilla: Facultad de Ciencias de la Información.

Ferré, P. (2001). Ciudad, cine, comunicación. Inmediaciones de la comunicación, 3, 55-60.

Gubern, R. (1998). Historia del cine. Barcelona: Editorial Lumen.

Harvey, D. (2008). París, capital de la modernidad. Madrid: Ediciones Akal.

Hueso, A. L. (2013). Ciudades europeas ante el objetivo de la vanguardia. En G. Camarero (Ed.), Ciudades europeas en el cine (pp. 15-26). Madrid: Ediciones Akal.

Hueso, A. L. (2014). París. Fantasía y realidad en las márgenes del Sena. En F. García \& G. M. Pavés (Coords.), Ciudades de cine (pp. 271-290). Madrid: Ediciones Cátedra.

Jeancolas, J. P. (1997). Historia del Cine Francés. Madrid: Acento Editorial.

Kovacsics, V. \& Marín, D. (2013). París de cine. Barcelona: Lunwerg Editores.

Londei, E. F. (1982). La Parigi di Haussmann. Roma: Edizioni Kappa. "La 'metamorfosi' di Parigi fu il primo ammodernamento globale della struttura urbana di una città capitalistico-industriale; e questo primato rese Parigi il modello della città-capitale, alla metà del XIX secolo". Traducción propia.

Mairie de Paris (s.f.). Paris. Parcours cinéma dans Paris, 6. Recuperado de: http://www.paris.fr/viewmultimediadocument?multimediadocume nt-id=50389 (o8-04-2014)

Mascarenhas, J. (2013). Entre Guitry y Tati. Construyendo dos Atlas de París. En G. Camarero (Ed.), Ciudades europeas en el cine (pp. 185-202). Madrid: Ediciones Akal.

Quijano, D. (2011). Causas y consecuencias de los 'Grands Travaux' de Haussmann en París. Clío, 37, Recuperado de: http://clio.rediris.es/n37/articulos/articulos_quijano.html (o1-042014).

Villanueva, D. (2008). Imágenes de la ciudad. Poesía y cine, de Whitman a Lorca. Valladolid: Cátedra Miguel Delibes.

Yeste, I. (1994-95). El cine como fuente documental para reconstruir la historia urbana de la ciudad. Artigrama, 11, 287-296.

Cómo citar: Navarro, A. (2014). "París visto por Cédric Klapisch. Entre la realidad y el simbolismo”. Fotocinema. Revista científica de cine y fotografía, 9, pp. 171-189 Disponible: http://www.revistafotocinema.com/index.php?journal=fotocinema 